\title{
Rasā’el-e fārsī. Éd. de Ma'ṣūme Nūr Moḥammadī, Tehrān, Daftar-e Našr-e Mīrāt-e Maktūb + Ahl-e Qalam, 1375/1997, 252 p.
}

Mohammad Ali Amir-Moezzi

\section{(2) OpenEdition}

Journals

Édition électronique

URL : http://journals.openedition.org/abstractairanica/36759

DOI : 10.4000/abstractairanica.36759

ISSN : 1961-960X

Éditeur :

CNRS (UMR 7528 Mondes iraniens et indiens), Éditions de l'IFRI

\section{Édition imprimée}

Date de publication : 15 mai 2001

ISSN : 0240-8910

Référence électronique

Mohammad Ali Amir-Moezzi, «Rasāel-e fārsī. Éd. de Ma'șūme Nūr Mohammadī, Tehrān, Daftar-e Našre Mīrāt-e Maktūb + Ahl-e Qalam, 1375/1997, 252 p. », Abstracta Iranica [En ligne], Volume 22 | 2001, document 335, mis en ligne le 17 février 2010, consulté le 13 octobre 2020. URL : http:// journals.openedition.org/abstractairanica/36759; DOI : https://doi.org/10.4000/abstractairanica. 36759

Ce document a été généré automatiquement le 13 octobre 2020

Tous droits réservés 


\title{
Rasā'el-e fārsī. Éd. de Ma'șūme Nūr Moḥammadī, Tehrān, Daftar-e Našr- e Mīrāt-e Maktūb + Ahl-e Qalam, 1375/1997, $252 \mathrm{p}$.
}

\author{
Mohammad Ali Amir-Moezzi
}

Il s'agit de l'édition de neuf épîtres doctrinales d'un savant shiite imamite apparemment inconnu par ailleurs. Dans son introduction bien documentée, l'éditrice croit néanmoins pouvoir déclarer que l'A. semble avoir vécu entre l'invasion mongole (milieu du $13^{\mathrm{e}} \mathrm{s}$.) et le début de l'époque safavide (début $16^{\mathrm{e}} \mathrm{s}$.), très probablement au $9^{\mathrm{e}} / 15^{\mathrm{e}} \mathrm{s}$. La liste des épîtres : 1. Dar yād kardan-e 'elm-hā az farị̄̂ va sonnat dar hame-ye sāl (un des titres retenus par les catalogues de manuscrits, édité à partir d'un manuscrit unique, pp. 45-132); 2. 'Aqā'id dīniyya (de haute qualité théologique et logique, édité à partir de sept manuscrits, pp. 133-170) ; 3. Hazā’in al-īmān (suite de l'écrit précédent? Édité à partir d'un manuscrit unique, pp.171-178); 4. Ușūl Hamsa: tawhìd, 'adl, nubuwwat, imāmat, ma'ād (suite de l'écrit précédent? À partir d'un manuscrit unique, pp. 179-188) ; 5. Ușūl va furū‘ (traité sans intitulé, titre donné par l'éditrice, à partir d'un manuscrit unique, pp. 189-200); 6. 'Aqā'id madhab šī $a$ (titre donné par l'éditrice, à partir d'un manuscrit unique, pp. 201-216) ; 7. ‘Aqā’id (manuscrit unique, pp. 217-224) ; 8. Ușūle dìn I (sans intitulé, manuscrit unique, pp. 225-232) ; 9. Ușūl-e dìn II (manuscrit unique, pp. 233-240). Exemple remarquable de belle prose persane théologique et philosophique. 
INDEX

Thèmes : 7. Islam

\section{AUTEURS}

MOHAMMAD ALI AMIR-MOEZZI

EPHE - Paris 